\title{
MUNICIPAL ECONOMY AND LAND USE RESTRICTIONS
}

\author{
William C. SMITH*
}

INTRODUCTION

The problem of maintaining a sound relationship between municipal development and the local budget was again brought to the foreground in the recent case of Beach v. Planning and Zoning Commission of Milford. ${ }^{1}$ The planning officials of Milford, Connecticut, had denied a property owner permission to subdivide his land on the grounds that the fire and police protection and school facilities which would be demanded by the increase in population in that area could not be furnished at that time in view of the community's financial condition. The Connecticut Supreme Court of Errors overruled this action on the narrow ground that the enabling act did not provide for those reasons as a basis of subdivision control. This problem has been especially acute during the period since World War II with the shift of urban population to the more rural areas of the larger municipalities, or to the smaller outlying communities. The community is faced with increased costs in maintaining schools and other public services. To offset this expenditure it must rely on the tax base of the property which is developed as a result of this shift in population and on the tax base of existing property. The former tax base should be at its optimum and the latter preserved. Haphazard development in the process of the community's growth may well result in neither and in unduly large expenditures. Land use restrictions are the community planner's primary tools with which he attempts to maintain this local economy.

Land use restrictions have been upheld as measures within the scope of the police power. ${ }^{2}$ The traditional concept of this power is that the state may impose reasonable restrictions upon individual freedom for the benefit of public health, safety, morals, and general welfare. While the concept has not been given a static definition, it has been carefully circumscribed by the courts. ${ }^{3}$ However, during the last half century the courts have tended to add "general prosperity" to the usual phrases mentioned. The Supreme Court of the United States stated, "We hold that the police power of a State embraces regulations designed to promote the public convenience or the general prosperity, as well as regulations designed to promote the

* B.A. I952, University of Buffalo; LL.B. 1955, Harvard Law School.

1 I4I Conn. 79, ro3 A.2d 8r 4 (1954).

${ }^{2}$ Village of Euclid v. Ambler Realty Co., 272 U.S. 365 (I926). For a brief discussion of the development of police power see Harold L. Reeve, The Influence of the Metropolis on the Concepts, Rules and Institutions Relating to Property c. II (1954) (a paper prepared for the Bicentennial Celebration of Columbia University).

${ }^{3}$ See ReEve, op. cit. supra note 2. 
public health, the public morals or the public safety." 4 Since then many state courts in reviewing or adjudicating rights involving land use restrictions have declared general prosperity to be within the scope of police power. ${ }^{5}$ In Wisconsin the court said that "If such regulations stabilize the value of property, promote the permanency of desirable home surroundings, and if they add to the happiness and comfort of the citizens, they thereby promote the general welfare." The New York Court of Appeals in Wulfsohn v. Burden ${ }^{7}$ was also among the first state courts to follow the federal expansion of police power. That court stated that "Changing economic conditions ... may make necessary or beneficial . . public regulation." However, because an objective may in principle justify the exercise of police power does not mean that the methods used are proper in a given case-the regulation, in the field of land use restrictions, must be reasonable as applied to the property which is restricted. ${ }^{9}$ This paper will be focused on the question of the extent to which communities may utilize the police power to ease the financial burdens which result from the șhift in population.

\section{ZoNing}

In its earlier years zoning was hailed for its effect in stabilizing and even increasing property values. ${ }^{10}$ However, this acclamation died as the method was used, and finally people working in the field admitted it to have a negligible effect in terms of finance, except perhaps at the most highly restricted residential level. ${ }^{11}$ The explanation for the former view may be that at the time one could generally perceive little more than the initial impact of zoning with which some change or arrest might be expected. But this impact could have little predictive value as to how zoning would operate in this country over a period of time.

The courts have been of little help to the planner in his attempt to bring zoning to the aid of the municipal coffers. Attempts to use it to economize municipal expenditures were defeated by early New Jersey decisions such as Ingersoll $u$. Village of South Orange. ${ }^{12}$ These cases consistently held that inability to supply such public

'Chicago, B. \& Q. Ry. v. Illinois ex rel. Drainage Comm'rs, 200 U.S. 56r, 592 (1906). See Bacon v. Walker, 204 U.S. 311,317 (I907).

'See, e.g., Miller v. Board of Public Works of City of Los Angeles, I95 Cal. 477, 485,234 Pac. 381, 383 (1925), appeal dismissed, 273 U.S. 781 (1927); Devaney v. Board of Zoning Appeals of City of New Haven, I32 Conn. 537, 539, 45 A.2d 828, 829 (1946); Schmidt v. Board of Adjustment of City of Newark, 9 N.J. 405, 415, 88 A.2d 607, 6r I (1952); Clifton Hills Realty Co. v. City of Cincinnati, 6o Ohio App. 443, 449, 21 N.E.2d 993, 997 (1938).

${ }^{\circ}$ State ex rel. Carter v. Harper, 182 Wis. $148,158,196$ N.W. 451,455 (1923).

7 24 I N.Y. 288 , r50 N.E. 120 (1925).

${ }^{8} 24$ I N.Y. at 299, I50 N.E. at I23. See Mansficld se Swett, Inc. v. Town of West Orange, 120 N.J.L. I45, I98 Atl. 225 (Sup. Ct. 1938).

${ }^{\circ}$ See Nectow v. City of Cambridge, 277 U.S. 183 (1928).

${ }^{10}$ See Lawson Purdy and Others, Zoning as an Element in City Planning, and for Protection of Property Values, Public Safety, and Public Health 7, 39, 43 (ig20).

${ }^{11}$ See Feiss, Zoning as a Positive Instrument of Planning, National Conference on Planning 275, 276-77 (A.S.P.O. 1946).

${ }^{12} 3$ N.J. Misc. 335, I28 Atl. 393 (Sup. Ct.), aff'd, I02 N.J.L. 218, 130 Atl. 721 (1925). Sce Karke Realty Associates v. Mayor and Aldermen of Jersey City, 104 N.J.L. 173, I39 Atl. 55 (1927); E. \& M. Land Co. v. Board of Adjustment of Newark, 4 N.J. Misc. 467 , 133 Atl. 413 (Sup. Ct. 1926); 
services as fire-fighting equipment and personnel was no ground for zoning restrictions; the city had a duty to furnish the services as it expanded. These decisions seemed to have influenced other jurisdictions. ${ }^{13}$ However, even at that time they were considered not to impose an unlimited duty on the city to supply fire protection for any amount of fire hazard that a landowner might create, ${ }^{14}$ and the building code was to some extent effective in securing protection from fire hazards. ${ }^{15}$ An indirect effect of fire hazard prevention is reduction of municipal expense, but the action is justified on grounds of public safety.

Even after the amendment to the New Jersey Constitution in 1927 validating zoning, the Ingersoll case was cited with approval, ${ }^{16}$ thus indicating that finances did not come within the scope of police power. Zoning would be a relatively ineffectual tool for planners if these early decisions were rigidly adhered to and the municipality were required to justify ordinances on a narrow view of public health, safety, morals, and welfare. Later decisions seem to have recognized this and have begun to indicate that "physical, economic, and social" conditions are proper factors to be considered in determining the most appropriate use of property and justifying the exclusion of industry from residential communities. ${ }^{17}$ However, the scope of consideration given to the economic factors appears limited in New Jersey by De Mott Homes at Salem, Inc. v. Margate City. ${ }^{18}$ There the court held invalid an amendment to a zoning ordinance restricting the plaintiff's property to single family dwellings, on a finding that the motivation behind the ordinance was fear of increased burdens on schools and public services with insufficient return in the form of taxes from the plaintiff's land to meet the expenditures. ${ }^{19}$ The case, however, has been distinguished as involving spot zoning discriminating against the property owner. ${ }^{20}$ Perhaps the clearest declaration by the New Jersey courts is found in Springfield Tp. $v$. Bensley ${ }^{21}$ where the proposition found in the early Ingersoll case was reiterated with vigor. The court said that it was "not concerned with the economics involved in the performance of the duty resting on the municipal authorities to

Michel v. Village of South Orange, 4 N.J. Misc. 302, I32 Atl. 337 (Sup. Ct. r926); Rudensey v. Board of Adjustment of Town of Montclair, 4 N.J. Misc. 103, I3I Atl. 906 (Sup. Ct. 1926); Eaton v. Village of South Orange, 3 N.J. Misc. 956, 130 Atl. 362 (Sup. Ct. 1925).

${ }^{13}$ See City of Youngstown v. Kahn Bros. Building Co., II2 Ohio St. 654, 148 N.E. 842 (1925).

${ }^{14}$ Caldweil v. Saul, 5 N.I. Misc. 165, 135 Atl. 691 (Sup. Ct. 1927).

${ }^{15}$ See, e.g., Harrison v. Board of Adjustment of Town of Montclair, 6 N.J. Misc. 570, 142 Atl. 353 (Sup. Ct. I928); Contras v. Mayor and Aldermen of Jersey City, 5 N.J. Misc. 59, 135 Atl. 472 (Sup. Ct. I926).

${ }^{10}$ Hirschorn v. Castles, I13 N.J.L. $27 \%$, 744 Atl. 21 r (Sup. Ct. 1934).

${ }^{27}$ Duffeon Concrete Products, Inc. v. Borough of Cresskill, I N.J. 509, 64 A.2d 347 (1949). See Matter of Fox Meadow Estates, Inc. v. Culley, 233 App. Div. 250, 252 N.Y. Supp. 178 (2d Dep't 1931), $a f f^{\prime} d, 261$ N.Y. 506, 185 N.E. 714 (1933).

${ }_{18} 136$ N.J.L. 330,56 A.2d 423 (Sup. Ct. 1947), affd, 136 N.J.L. 639, 57 A.2d 388 (x948).

10136 N.J.L. at 334,56 A.2d at 426 .

${ }^{20}$ Guaclides v. Borough of Englewood Cliff, ir N.J. Super. 405, 78 A.2d 435 (App. Div. 1952). Ridgefield Terrace Realty Co. v. Borough of Ridgefield, $x 36$ N.J.L. 3 II, 55 A.2d 812 (Sup. Ct. 1947) was distinguished on the same grounds in Guaclides. In the Ridgefield case the court refuted the community's argument that the proposed apartment houses would overtax the schools and other public services.

${ }^{21} 19$ N.J. Super. 147, 88 A.2d 27I (Ch. 1952). 
furnish required facilities as and when and to the extent needed. The duty is paramount."22 Weight given to economic factors has not invalidated zoning ordinances where the ordinance may be justified on other grounds, ${ }^{23}$ or rendered illegal action denying an application for a variance. ${ }^{24}$

Most enabling acts have a provision similar to that found in the New Jersey statute which requires that zoning regulations be made "with a view of conserving the value of property and encouraging the most appropriate use of land. . .."25 This provision is relied upon by cases permitting some consideration of economic factors. It would aid the planner at least to the extent that zoning for the most appropriate use of property and enforcing a uniform use for the particular neighborhood is effective in decreasing the loss of property value and thus maintaining the tax base. The grant of power is a negative one, however, for courts have held invalid attempts to use it to enhance the value of property and in that way to increase revenue. ${ }^{26}$ One could have little quarrel with this result as a matter of statutory construction. If the enabling act expressly provided for the enhancement of value there is some language indicating that zoning regulations enacted pursuant to the provision might be sustained. ${ }^{27}$ However, even then the regulation must pass the test of reasonableness. to be upheld as a valid exercise of police power. Use of zoning to set up minimum values for buildings ${ }^{28}$ or to maintain a low tax rate or to exclude the conservative spender from the community ${ }^{20}$ has not been encouraged by the courts.

Those jurisdictions refusing to sustain zoning ordinances based upon economic considerations might rule differently under the Illinois enabling act which empowers municipalities to zone "To the end ... that the taxable value of land and buildings throughout the municipality may be conserved...."30 The statute further provides that in enacting all ordinances "due allowance shall be made for existing conditions,

22 Ig N.J. Super. at 158,88 A.2d at 277 .

${ }^{23}$ Greenway Homes v. Borough of River Edge, I37 N.J.L. 453, 60 A.2d 8I I (Sup. Ct. I948); Putney v. Township of Abington, $176 \mathrm{~Pa}$. Super. 463, 108 A.2d 134 (1954).

24 See Shipman v. Town of Montclair, I6 N.J. Super. 365, 370, 84 A.2d 652, 654 (App. Div. 1951).

${ }^{26}$ N.J. Stat. Ann. \$40: 55-32 (1940). See, e.g., N.Y. Gen. City Law \$20(25); Mich. Stat. ANN. $\$ 5.2931$ (1949).

${ }^{26}$ I22 Main Street Corp. v. City of Brockton, 323 Mass. 646, 84 N.E.2d I3 (1949); Brown v. Board of Appeals of City of Springfield, 327 Ill. 644, I59 N.E. 225 (1927).

${ }^{27}$ See Putney v. Township of Abington, supra note 23, at ro8 A.2d at 138 . The Alaska enabling act provides that the regulations be made with a view to enhancing the value of property. Alaska Comp. Laws ANn. $\$ 16-1-35$ (1949).

${ }^{28}$ See Haar, Zoning for Minimum Standards: The Wayne Township Case, 66 Harv. L. REv. 1051, 1055 (1953).

${ }_{20}$ See Simon v. Town of Needham, 311 Mass. 560, 565-66, 42 N.E.2d 516, 519 (1942). But see Rodgers v. Village of Tarrytown, 302 N.Y. 115,96 N.E.2d 731 (195I). The court there upheld an amendment to the zoning ordinance, the enactment of which was motivated by a finding of nced for housing and a desire to relieve the tax burden of the small home owner.

${ }^{30}$ Ill. AnN. Stat. c. 24, § 73-I (Supp. 1954). See Gill, Minimum Height Restrictions in Brockton, in Municipalities and the Law in Action, Proceedings of the 1946 Annunl Conference of the National Institute of Municipal Law Officers 250, 255 (Rhyne ed. 1947). He suggests that under this provision there is more likelihood of the courts' sustaining minimum height restrictions. But see Brown v. Board of Appeals of City of Springfield, 327 Ill. 644, I59 N.E. 225 (I927). 
the conservation of property values, the direction of building development to the best advantage of the entire municipality and the uses to which the property is devoted at the time of the enactment of such an ordinance."31 Again it is to be noted that the statute provides for the conservation and not the enhancement of value. The Illinois Supreme Court has given effect to the provision that conservation of the aggregate taxable value of property in the community is a goal of zoning. The provision seems intended for the benefit of the municipal unit. The court sustained a zoning ordinance under which the attacking owner's property was worth 50 per cent less than it would have been under the use to which the owner sought permission to change it. ${ }^{32}$ In that case the city introduced evidence to the effect that loss in value of the neighboring property and thus of tax revenue to the city would outweigh any possible gain to the attacking property owner. The petitions of neighboring residential property owners that the use be allowed were held not to alter the case. In fact, the court has stated that preventing loss of taxable value alone would be sufficient basis for an ordinance. ${ }^{33}$ The provision that in enacting all ordinances due allowance be made to conservation of property values would seem intended for the benefit of individual property owners. The court has recognized the right of the individual by holding invalid an amendment to a zoning ordinance upon a showing by owners of property adjacent to the rezoned district that due allowance was not made. ${ }^{34}$ Such a distinction between the parties intended to be benefited by the two provisions in the Illinois statute has the advantage of not imposing a strict duty upon the city of maintaining the taxable value of all property. In view of possible conflict between the various purposes of zoning stated in enabling acts, the municipality would seem to be in the best position to determine which purpose is most beneficial to it at a given time. Some jurisdictions hold that the economic consequences to the city flowing from a change to a less restrictive ordinance involve questions of policy and business judgment committed to the "honest judgment" of community officials. ${ }^{35}$

Enabling acts containing only the provision that zoning regulations be made with a view of conserving property values leave vague standards for determining the identity of the party intended to be benefited. The community may prevail over the property owner in causing a loss of property value so long as the end is within the scope of the police power and reasonable. A landowner is protected by the fact that the conservation of his property value is usually to the benefit of the municipal

${ }^{31}$ ILL. ANn. Stat. c. 24, $\$$ 73-I (Supp. r954).

${ }^{32}$ Dunlap v. City of Woodstock, 405 Ill. 410, 9I N.E.2d 434 (1950). The same provision of the statute was held to negate a showing that a single family residence zoning ordinance was unreasonable as to plaintiff's property when the defendant city introduced evidence that the use of plaintiff's property as a multi-family residence would depreciate neighboring property value and diminish tax revenue. Jacobson v. Village of Wilmette, 403 Ill. 250,85 N.E.2d 753 (1949).

${ }^{33}$ Neef v. City of Springfield, 380 Ill. $275,28 \mathrm{r}, 43$ N.E.2d 947,950 (x942). The plaintiff property owner attempted to have zoning of his property changed from residential to allow construction of a gasoline station. There were other grounds on which the ordinance could have been sustained.

${ }^{34}$ Michigan-Lake Building Corp. v. Hamilton, 340 Ill. 284, I72 N.E. 710 (1930).

${ }^{35}$ Hendlin v. Fairmount Const. Co., 8 N.J. Super. 3ro, 72 A.2d $54 \mathrm{I}$ (Ch. 1950). 
budget. The taxable revenue to be derived from the property is in direct proportion to the value of the property. However, a particular landowner would not be protected if a city empowered to zone with a view to raising revenue does so by extending a manufacturing district in such a way that residences in a neighboring residential district depreciate in value. A zoning change from residential to industrial has been sustained where it was found that a buffer area prevented depreciation of residential property, that the land changed could not economically be used as residential property, and that there was a comprehensive plan. The court stressed the resulting tax benefit to the town and the smaller demand for schools and public services than would have been created had a residential development been fostered. ${ }^{30}$ However, where there would be depreciation of nearby residential property and the owner of the rezoned property could have economically continued the original use, it is doubtful that fiscal considerations alone would have justified the rezoning. ${ }^{37}$

Municipalities have recently found some aid in combating haphazard growth of their fringe areas in minimum lot size and minimum floor area restrictions. The former is perhaps the more effective in terms of controlling rapid development of particular districts and perhaps the one more often recognized by the courts. In 1942, the Massachusetts court upheld a minimum lot size requirement of one acre for single family dwellings. ${ }^{38}$ There the court noted that "The expense that might be incurred by a town in furnishing police and fire protection, the construction and maintenance of public ways, schoolhouses, water mains and sewers and other public conveniences might be considered as an element more or less incidently involved, in the adoption of a zoning by-law that will promote the health, safety, convenience, morals or welfare of the inhabitants of the town without imposing any unreasonable and arbitrary burden upon the landowners. ${ }^{.39}$ This would seem another indication that although municipal finances alone may not serve as a basis for zoning restrictions, they may be considered as one of the factors in the over-all formulation of zoning policy. ${ }^{40}$ The court indicated that this type of zoning could not be used to maintain a low tax rate. ${ }^{41}$ Since then a minimum lot restriction as high as five acres per residence has been upheld as furthering "the advancement of a community as a social, economic and political unit. ..."42 The Missouri Supreme Court up(1953).

sn Hills v. Zoning Commission of Town of Newington, 139 Conn. 603, 609, 96 A.2d 212, 215

${ }^{37}$ See Lippow y. City of Miami Beach, 68 So.2d 827 (Fla. 1953). The court stated that stabilization and enhancement of property values in a particular district would not in itself be sufficient to justify the zoning ordinance.

${ }^{38}$ Simon v. Town of Needham, 311 Mass. 560,42 N.E.2d 516.

39 3II Mass. at 565,42 N.E.2d at 519 .

${ }^{10}$ But see Appeal of Elkins Park Improvement Ass'n, 361 Pa. 322, 327-28, 64 A.2d 783, 785 (1949). The court in overruling refusal of a variance from a 7500 square fect per family restriction stated that fear of financial burdens in providing for maintenance of schools and police protection was not a controlling consideration in the case.

${ }^{11}$ Simon v. Town of Necdham, 31I Mass. at 566, 42 N.E.2d at 519.

${ }^{42}$ Fischer v. Bedminster Tp., II N.J. 194, 203, 93 A.2d 378, 382 (1952). Sce Dilliard v. Villagc of North Hills, 276 App. Div. 969, 94 N.Y.S.2d 7 r5 (2d Dep't r950) (two acre minimum upheld; 
held a three acre minimum restriction where the attacking property owner's land adjoined land in other villages zoned for similar lot sizes. ${ }^{43}$ The city defended the ordinance on the ground that smaller lot sizes would cause an increase in population which would unbalance the plan for schools, improvements, and fire and police protection to be made in accordance with zoning recommended by city planners. ${ }^{44}$ In view of these facts the court thought that the exclusion of the plaintiff's property from the ordinance would disrupt the general zoning planned for the benefit of the community.

Minimum lot size zoning can be sustained as a regulation of population density when done in accordance with a comprehensive plan-a purpose common to most enabling acts. ${ }^{45}$ These ordinances imposing minimum lot sizes of one to two acres are fairly easily justified on grounds of public health, safety, and general welfare. Because of this some cities have used the device to prevent overcrowded developments yielding insufficient tax return for the services which would have to be supplied, where the city would not be able to justify zoning on the grounds of municipal economy. ${ }^{46}$ However, in using this device to control future development the community must be prepared to show that the time of anticipated residential use of the land can be fixed with some degree of certainty and that the property is suitable for the use zoned. Otherwise the ordinance may well be struck down as an unreasonable restriction. ${ }^{4 \tau}$ This consideration may cause doubt as to the propriety of highly restrictive zoning at fringe areas of the community, where to the present time little development has taken place. Development at the fringe areas still at great distances from previously built-up sections of the community would not seem to alter the problem greatly when the community attempts to zone under the traditional concept of police power. However, if police power were held to include protection of municipal finances the problem might be to some extent eliminated. The city might be able to show that regulation has a more substantial relationship to the municipal economy than it would have to the traditional concepts of police power.

Minimum floor area restrictions were upheld by the New Jersey court in Lionshead Lake, Inc. v. Township of Wayne. ${ }^{48}$ The court noted that without this type of restriction there would be danger of the lakes in the area attracting summer visitors who would erect buildings of such inferior quality that the general value

however, here the plaintiff had purchased the property with knowledge of the ordinance and had sold 4 of the 48 acres for more than half the purchase price). In Gignoux v. Village of Kings Point, 199 Misc. 485,99 N.Y.S.2d 280 (Sup. Ct. 1950), the court upheld an amendment changing the minimum restriction from 20,000 square feet to 40,000 square feet per dwelling.

${ }^{43}$ Flora Realty \& Investment Co. v. City of Ladue, 362 Mo. 1025, 246 S.W.2d 771 (1952), appeal dismissed, 344 U.S. 802 ( 1952 ).

${ }^{14} 362$ Mo. at $1036-37,246$ S.W.2d at 776 .

"E.g., ME. Rev. Stat. c. 9x, \$93 (1954).

"Interviews with city planning officials.

${ }^{4}$ See Arverne Bay Construction Co. v. Thatcher, 278 N.Y. 222, I5 N.E. $2 d 587$ (1938); Forde v. City of Miami Beach, $x_{4} 6$ Fla. 676 , I So.2d 642 (I94I).

is ro N.J. I65, 89 A.2d 693 (1952), appeal dismissed, 344 U.S. 9 I9 (1953). 
of property would decrease and result in large loss to the permanent residents of the area. ${ }^{49}$ This type of zoning has not met with the same extent of judicial approval as have minimum lot size restrictions. ${ }^{50}$ In Medinger Appeal ${ }^{j 1}$ the Pennsylvania Supreme Court recently said "We therefore hold that neither aesthetic reasons nor the conservation of property values or the stabilization of economic values in a township are, singly or combined, sufficient to promote the health or the morals or the safety or the general welfare of the township or its inhabitants or property owners within the meaning of the enabling Act of $\mathrm{x}_{93} \mathrm{I}$, as amended, or under the Constitution of Pennsylvania." 52 Although the Pennsylvania enabling act does not specifically provide for preservation of property value, it does authorize regulation and restriction of building size and height as well as of density of population "For the purpose of promoting health, safety, morals, or the general welfare of townships. ..."53 If the court had not been disposed to construe zoning legislation strictly, it might be argued that conservation of property value is an element of "the general welfare." ${ }^{54}$

While minimum floor area restrictions have the advantage of not being subject to the objection that a landowner is deprived of his right to build because his lot size is too small, ${ }^{55}$ they have been attacked as economic segregation and as designed for the purpose of protecting high cost buildings. ${ }^{50}$ The attack has been countered with the suggestion that one should not be shocked by this fact because zoning in many cases results in ecomonic segregation. An example offered is the economic hardship imposed on property owners who would derive income from their houses if they were zoned multi-family rather than single residence or if zoning allowed a store in part of their homes. ${ }^{57}$ Once it is established that preservation of property values is a proper basis of zoning, it would seem that the next question is whether the particular restriction imposed is related to that purpose and whether the exercise of the power in a given case is reasonably calculated to effect that goal. ${ }^{68}$ If a district has developed to some extent with high cost houses, zoning with minimum

18 1o N.J. at 175,89 A.2d at 698.

${ }^{80}$ See Haar, Zoning for Minimum Standards: The Wayne Tounship Case, 66 Harv. L. Rev, 1051, 1059 (1953) and cases there cited.

51 377 Pa. 217, 104 A.2d at 118 (1954).

${ }_{52} 377 \mathrm{~Pa}$. at 226,104 A.2d 122 .

${ }^{63}$ Pa. Stat. ANN. tit. 53, \$19092-3101 (Supp. 1953).

${ }^{6}$ See Schloemer v. City of Louisville, $298 \mathrm{Ky} .286,289$, $x 82$ S.W.2d 782, 784 (1944). The court said that preventing a decrease in the value of neighboring property was directly related to public welfare. The Kentucky enabling act, however, did provide that zoning be done with a vicw of conserving property value. Ky. REv. STAt. ANN. \$roo.066 (r943).

${ }^{55}$ See Babcock, Classification and Segregation Among Zoning Districts, 1954 U. ILL. Law Fonum I86, I97.

${ }^{68}$ See Haar, Zoning for Minimum Standards: The Wayne Township Case, 66 HARv. L. Rev. 1051 (1953); Haar, Wayne Township: Zoning for Whom?-In Brief Reply, 67 Hanv. L. Rev. 986 (1954). Professor Haar is of the opinion that sliding scale minimum floor areas for different districts tailored to various land uses smack even more of economic segregation. He notes that the Pennsylvania court recognizes that here health justification is no longer present, for it is difficult to say that onc size house is healthy in one district and detrimental to health in another. $66 \mathrm{HARv}$. L. REv. at ro56-57.

${ }^{67}$ See Babcock, supra note 55, at $20 \mathrm{x}$.

${ }^{68}$ Sec Babcock, supra note 55, at 202. 
floor area restrictions would tend to cause houses built at a later date to be on a par or closely approximate in value the original houses. But in an area already quite fully developed and with few vacant lots a minimum floor area requirement for future homes requiring, as a practical matter, buildings highly disproportionate in cost to surrounding buildings may well be struck down as unreasonable. The basic assumption in this area seems to be that the cluster of low cost houses that might be developed were it not for these restrictions would create a financial burden on the community not reimbursed in the form of taxes to a far greater extent than would large, less densely packed homes. ${ }^{59}$ However, it is possible that the former type development would attract the lower income groups who because of their financial condition are more likely to remain in and patronize that area. If this is true, an interesting question arises as to whether this increased local business compensates for the smaller tax return from the property.

\section{Subdivision Control}

Another approach to the control of haphazard development is through subdivision control. Under this system of control, enabling acts provide that planning boards may adopt an official plan or map of the community. ${ }^{60}$ The planning board may be authorized to approve or disapprove or modify plats of proposed subdivisions. ${ }^{61}$ Plats submitted for approval should, where an official plan has been adopted, be co-ordinated with that plan "so as to compose a convenient system conforming to the official map and properly related to the proposals shown by the planning board on the master plan...." ${ }^{22}$ Where these statutes provide for master plans, municipal authorities should follow the statutory steps in adopting the plan if they wish to rely upon it in disapproving plats for improperly placed roads. ${ }^{63}$ Also if the enabling statute provides that regulations are to be adopted for the purpose of regulating subdivisions, the planning body must not mix its legislative and administrative functions. ${ }^{64}$

Some enabling statutes provide that, prior to approval, the planning board may require such things as the following: streets sufficiently wide for prospective traffic and for access for fire-fighting equipment, graded, paved, and provided with curbs and gutters; and water mains, sanitary sewers, and storm drains or combined sewers installed in accordance with standards set up by the appropriate municipal department. ${ }^{05}$ The statute may provide that this be done at the expense of the subdivider or that the community do it with the subdivider furnishing a performance bond. ${ }^{66}$

${ }^{\circ}$ There was some evidence to this effect in Simon v. Town of Needham, 3 Ir Mass. 560, 565, 42 N.E.2d $5 \times 6,5 \times 9(1942)$.

${ }^{\circ 0}$ N.Y. Town LAw $\$ 272-a$. See $\$ \$ 270,273$.

01 N.Y. Town Law $\$ 276$.

${ }^{62}$ N.Y. Town Law $\$ 277$.

${ }^{03}$ E.g., Lordship Park Ass'n v. Board of Zoning Appeals of Town of Stratford, 137 Conn. 84, 75 A.2d 379 (1950). Where there is no official map the statute may provide that the proposed roads be properly related to the existing street system. See N.J. Stat. ANN. $\$ 40: 55-1.20$ (Supp. 1954).

${ }^{\circ 4}$ See Beach v. Planning and Zoning Commission of Town of Milford, supra note $\mathrm{r}$.

${ }^{o t}$ E.g., N.Y. Town LAw $\$ 277$. The planning board may waive these requirements if in the interest of public health, safety, and general welfare.

${ }^{\infty}$ Ibid. 
Where a court finds that a master plan has been adopted, conditions placed on plat approval such as dedication of land for streets of greater width than existing public streets have been upheld as well as conditions requiring dedication of land for trees and shrubbery. ${ }^{67}$ Some enabling acts provide that a subdivider may place a notation on his plat when submitted for recording that the streets are not to be considered public. The streets in such a case remain private until formally offered to and accepted by the public or until they are taken by eminent domain. ${ }^{08}$ However, pressure for an offer to the public is imposed by a provision that no public municipal street utility be constructed on any street until it is public and placed on the official map, unless it is a subsurface utility operated for revenue. ${ }^{60}$

Subdivision controls seem aimed at preventing a property owner from realizing a profit at the expense of the community to the extent that he must provide for the initial cost of laying streets and public services such as water and sewerage. However, little of this aids in controlling population density or the number of residences that may be a continuing burden on the community in terms of maintaining the services. It is here that the relationship between subdivision control and such zoning restrictions as minimum lot size requirements comes into play. Statutes authorizing subdivision control may provide that the plat conform to the zoning regulations in force ${ }^{70}$ or that minimum lot sizes be specified in the subdivision ordinance. ${ }^{71}$ Land use restrictions would be of aid to the community in this situation only in so far as the activity sought to be controlled takes place within its jurisdiction. Thus where an enabling statute allows the community to zone or control subdivision only to its border there is nothing the community can do to prevent a property owner outside that area from subdividing land with complete disregard for the future consequences of his action. There may be some relief against this danger in a jurisdiction giving the community power to annex surrounding property on a showing of necessity. ${ }^{72}$ In such a case the community would not necessarily be bound by a negative vote of the electorate in the district to be annexed and thus would seem to possess a greater freedom of action. The problem may also be alleviated to some extent by such statutes as that in Illinois giving the community jurisdiction to prepare plans and control subdivision in the contiguous territory one and one-half miles beyond the corporate limits. ${ }^{73}$ However, where enabling acts give cities, counties, towns, and villages power to adopt zoning regulations and subdivision control, the town may be limited to its area outside that of an incorporated village or city. ${ }^{\mathbf{7 4}}$ There may be a problem here of a conflict between

${ }^{o r}$ Ayres v. City Council of City of Los Angeles, 34 Cal.2d 31, 207 P.2d I (1949). If there is no master plan or official plan the New Jersey statute provides that no greater width than 50 fect be required. N.J. Stat. ANN. \$ 40:55-1.20 (Supp. r954).

${ }^{o s}$ See N.Y. Town LaW $\$ 278$.

${ }^{00}$ N.Y. Town Law $\$ 280$.

${ }^{20}$ E.g., N.Y. Town Law $\$ 277$.

${ }^{71}$ N.J. Stat. ANN. \$40:55-I.I5 (Supp. 1954).

${ }^{72}$ See Norfolk County v. City of Portsmouth, I86 Va. ro32, 45 S.E.2d r36 (1947).

${ }^{73}$ ILl. ANN. Stat. c. 24, $\$ 53.2$ (1942).

"See N.Y. Town Law $\$ \$ 26 \mathrm{x}, 276$. 
the standards of, say, a town and a city. Where the town's standards are lower than those of the city, subdivision taking place under the town's standards may work to the detriment of the city upon subsequent annexation.

In as much as zoning and subdivision control are both accomplished by the exercise of police power, it would seem that the considerations applicable to the former would also apply to the latter. However, some jurisdictions regard recordation of the subdivision plat a privilege and allow a community to impose reasonable conditions before the privilege is granted. ${ }^{75}$ Under such reasoning the community may be able to exercise more control than would be possible under the traditional doctrine of police power.

\section{Conclusion}

There is a great area of uncertainty as to the extent communities may consider financial burdens in formulating zoning or subdivision policy. Most cases indicate that it may be considered as part of the over-all picture. Indeed, its consideration does not invalidate the action when there exists adequate justification on other grounds. Active use of land use restrictions to increase revenue would seem to be invalid absent a provision in the enabling act, except in practical effect where minimum floor area regulation has been upheld. ${ }^{76}$ It has been suggested that the proper justifications for minimum standards in zoning are not the traditional subjects of police power, but rather preservation of property value and hence conservation of tax base. ${ }^{77}$ Attempts to attain this objective may be enhanced by provisions in the enabling statute, such as that of Illinois, that preservation of "taxable value" is a purpose of zoning. Once public economy is acknowledged as a justification for the exercise of police power, the means of control would seem to be through preservation of property value. In such a case it is difficult to see how an attack that existing investments are being protected can succeed. When an individual or a particular group of people is protected at the expense of the remainder of the community the attack might be sustained, for the police power is being used to discriminate among

${ }^{75}$ See Ridgefield Land Co. v. City of Detroit, 241 Mich. 468,217 N.W. 58 (1928); Carter, J. dissenting in Ayres v. City Council of City of Los Angeles, 34 Cal.2d 3x, 43, 207 P.2d I, 8 (x949).

70 The Georgia enabling act provides that the regulations "be made in accordance with a comprehensive plan designed for the purposes, among others, of . . . encouraging such distribution . . . of land development and utilization as will tend to facilitate economic and adequate provisions for transportation, communications, roads, airports, water supply, drainage, sanitation, education, recreation or other public requirements. . . Such regulations shall be made with reasonable consideration, among others, to ... securing economy in governmental expenditures. ..." GA. Code ANN. \$69-802 (Supp. I95r).

${ }^{77}$ Babcock, supra note 55, at 20x. See Landels, Zoning: An Analysis of Its Purposes and Its Legal Sanctions, 17 A.B.A.J. 163 (I93I). At page $165 \mathrm{Mr}$. Landels states that "On analysis the primary objects of zoning are found to be ... the protection of the value . . . of urban land, and the assurance of such orderliness in municipal growth as will facilitate the execution of the city plan and the economical provision of public services."

In the course of interviews with city planning officials the writer was made aware of the fact that although exclusion of multi-family dwellings from single family zones is justified as a means of securing protection of health and fire safety, the planning officials are primarily concerned with the reduced municipal expenditures and increased tax return involved when the community decreases the number of multi-family dwellings in favor of more single family residences. 
members of the community. The exercise of police power should be held to the constitutional test of reasonableness when used to protect municipal finances as it is when used for the traditional subjects of police power. However, absent that factor, preservation of taxable value would seem different from the other concepts for here what is good for the community will on the whole be good for the property owner. Once given the power to regulate in this manner the community almost has to protect the property owner.

Preservation of taxable value as a justification will produce results raising at least two related problems. One is that pronounced economic segregation will be a practical effect. It would seem that sliding scale minimum floor area zoning would be valid if it need no longer be justified on grounds of health. In such a case the income groups will be forced to seek the district which allows the size house they are financially able to afford. A single minimum floor area requirement for the community may force low income groups to migrate to other areas where they may be faced with the same situation or the second area may be forced to adopt similar measures to prevent a sudden influx of people. This raises the question of the unit which is to be used in zoning. ${ }^{78}$ Focusing solely on local conditions may produce detrimental effects in the surrounding areas that will have repercussions at some future time. The problem may also arise from situations in which communities zoned purely residential rely on neighboring communities for such things as stores and schools. ${ }^{79}$ While the neighboring communities will benefit from the increased business, they will also be educating children for whom there will be no reimbursement in the form of taxes. Even if the schools receive tuition for these children there remains inconvenience in the arrangement. Perhaps some sort of regional unit should be adopted with less stress by the courts on the local aspect.

\footnotetext{
${ }^{78}$ See Haar, Zoning for Minimum Standards: The Wayne Tounship Case, 66 HARv. L. Rev. 105T, 1053 (1953).

${ }_{79}^{7}$ See Gignoux v. Village of Kings Point, 199 Misc. 485,99 N.Y.S.2d 280 (Sup. Ct. 1950).
} 